\title{
INTEGRATED PRECIPITABLE WATER VAPOUR MEASUREMENTS AT POLISH POLAR STATION HORNSUND FROM GPS OBSERVATIONS VERIFIED BY AEROLOGICAL TECHNIQUES
}

\author{
Michał Kruczyk, Tomasz Liwosz \\ Department of Geodesy and Geodetic Astronomy \\ Faculty of Geodesy and Cartography, Warsaw University of Technology \\ Warsaw, Poland
}

\begin{abstract}
We present results of the comparison of integrated precipitable water measurements from GPS solution and aerological techniques: CIMEL-318 sun-photometer and radiosoundings (RAOB). Integrated Precipitable Water (IPW) - important meteorological parameter is derived from GPS tropospheric solutions by known procedure for GPS station at Polish Polar Station, Hornsund (Svalbard). The relation between $2 \mathrm{~m}$ temperature and the mean temperature of atmosphere above, used to convert from wet part of tropospheric delay (ZWD) to IPW, has been derived using local radiosonde data at Ny Alesund. Sunphotometer data have been provided by AERONET. Quality of dedicated tropospheric solutions has been verified by comparison with EPN tropospheric combined product. Several IPW comparisons and analyses lead to determination of systematic difference between techniques: GPS IPW and sunphotometer data (not present in case of RAOBs). IPW measured by CIMEL is on average $5 \%$ bigger $(0.5$ $\mathrm{mm}$ ) than IPW from GPS. This bias changes seasonally and is a function of atmospheric temperature what signals some systematic deficiencies in solar photometry as IPW retrieval technique. CIMEL IPW show some temperature dependent bias also in relation to radiosoundings.
\end{abstract}

Keywords: Water Vapour, GPS, IPW, IWV, Tropospheric Delay, Sunphotometer, Radiosoundings, Polar Research

\section{Introduction}

Atmospheric refraction of Global Positioning System (GPS) L-band navigational signal manifests itself in the form of tropospheric delay. For GPS measurement taken between a satellite at zenith and a receiver located at sea level, the zenith tropospheric delay (ZTD), in units of length, amounts to approximately $2.3 \mathrm{~m}$. The 
ZTDs need to be properly taken into account if high accuracy of station coordinates is needed, i.e., at the level of several millimeters. Valuable geodetic coordinate solutions for antenna phase center should be at centimeter level (daily solutions). Due to limited accuracy of existing ZTD models, the most precise applications of GPS (geodynamics, geodetic reference frames), require the estimation of ZTDs during the adjustment of GPS observations, together with other parameters, e.g., station coordinates, phase ambiguities. Because of temporal variability, ZTDs are usually estimated every one hour for each station (24 parameters for daily session). So we eliminate tropospheric delay in GPS solutions by the proper construction and solution of observational equation system so as tropospheric delay is estimated stochastically together with coordinates (Hoffman-Wellenhof B., 2008; chapter 5.3). In case of permanent GPS stations (maintained for most precise scientific solutions) the GPS derived ZTDs are also used for the purposes of atmospheric research and are the basis for GPS meteorology (Duan et al., 1996). ZTD is a sum of zenith wet delay (ZWD) and zenith hydrostatic delay (ZHD). ZWD, which is about $10 \%$ of ZTD, depends mostly on the content of water vapour along the path of signal propagation and is highly variable both spatially and temporally. ZHD depends mostly on surface atmospheric pressure, and can be computed at the several millimeter accuracy level from existing ZHD models using surface meteorological data. In this work Saastamoinen formula with gravitational correction (function of surface atmospheric pressure) serves as ZHD model.

A number of studies have shown that IPW estimates from ground-based GPS observations and meteorological/aerological data give the same level of accuracy as radiosondes and microwave radiometers (see e.g. Vedel et al., 2001). In this work both radiosoundings and another water vapour data source - sun photometer are tested in exceptional conditions: at polar station.

An independent source of IPW can be obtained in CIMEL-318 sun photometer important tool in aerosol research (Holben et al., 2001, Halthorne et al., 1997). This valuable devices are operated in the frame of AERONET (AErosol RObotic NETwork) network coordinated by NASA \& CNRS (http://aeronet.gsfc.nasa.gov/). Multichannel radiometer measures many air properties (mostly aerosoles) registering absorption lines of solar spectra and gives also IPW values (precisely - slant values in the direction to the Sun). Water vapour channel used is $940 \mathrm{~nm}$ and $1020 \mathrm{~nm}$, potentially also $1640 \mathrm{~nm}$. The relationship used to estimate the PW from the water vapour transmittance $T_{w v}$ is:

$$
T_{w v}=e^{-a \cdot(m \cdot I P W)^{b}}
$$

The two constants $a$ and $b$ are related to the used water vapour channel and $m$ is the relative optical airmass:

$$
m=\int \rho \cdot d s / \int \rho \cdot d z
$$

Where $s$ is the slant path of the solar ray, $z$ is the vertical path. 
Several investigations have been carried out to evaluate sunphotometer IPW by other techniques, also GNSS (see e.g. Pérez-Ramírez et al., 2014).

\section{GNSS Observations at Hornsund and its Processing}

Polish Polar Station (of the Institute of Geophysics and the Institute of Polar Research, Polish Academy of Sciences) in Hornsund fjord (Svalbard, latitude $77.00^{\circ} \mathrm{N}$, longitude $15.55^{\circ} \mathrm{E}$ ) operated permanently GNSS station (Leica GRX 1200 PRO sn. 463098 with AT504 antenna). Antenna location has been changed to the technical reasons in 2009 (so we have two points ASTR and AST0). Orthometric height (calculated with EGM96) have increased from 10 to $18 \mathrm{~m}$. CIMEL CF-318 is mounted in close vicinity of GPS station, and its processed measurement results are available through AERONET.

The campaign data (from June 2008 till November 2010) has been processed according to the EUREF Local Analysis Centres guidelines using Bernese GPS Software ver. 5.0 (Dach et al., 2007). We processed Hornsund data together with a subset of 20 EUREF Permanent Network stations. GPS data were processed in daily sessions and ZTDs were estimated in 1-hour intervals for all stations in the network.

We compared our ZTD solutions with EPN combined tropospheric product (standard product of EPN network created as iterative weighted mean of individual analysis centers solutions). Results are quite satisfying: for most of stations this solutions in comparison with EPN combined tropospheric product show ZTD biases below $1 \mathrm{~mm}$ level. E.g. results for 2009 are as follows: average bias $0.024 \mathrm{~mm}$, difference RMS $1.83 \mathrm{~mm}$.

Table 1. Comparison of ZTD from test campaign (WUT LAC network solution for Hornsund) with EPN combined tropospheric product in 2009

\begin{tabular}{|c|c|c|c|c|c|}
\hline GPS station & bias [mm] & $\begin{array}{c}\text { absolute } \\
\text { difference [mm] }\end{array}$ & $\begin{array}{c}\text { standard } \\
\text { deviation [mm] }\end{array}$ & RMS [mm] & $\begin{array}{c}\text { ZTD } \\
\text { points }\end{array}$ \\
\hline BOR1 & 0.18 & 1.53 & 2.05 & 2.06 & 8370 \\
\hline HOFN & -0.14 & 0.96 & 1.29 & 1.29 & 8382 \\
\hline JOZ2 & 0.42 & 1.73 & 2.26 & 2.3 & 7625 \\
\hline JOZE & 1.53 & 2.19 & 2.44 & 2.88 & 8156 \\
\hline LAMA & 0.33 & 1.5 & 2.1 & 2.12 & 8359 \\
\hline MAR6 & -0.61 & 1.04 & 1.19 & 1.34 & 8416 \\
\hline NYA1 & 0.25 & 1.09 & 1.48 & 1.5 & 7980 \\
\hline ONSA & -0.26 & 1.08 & 1.39 & 1.42 & 8185 \\
\hline OSLS & -0.75 & 1.3 & 1.48 & 1.65 & 8086 \\
\hline QAQ1 & -0.42 & 2.01 & 2.7 & 2.73 & 8424 \\
\hline REYK & 0.22 & 1.23 & 1.65 & 1.66 & 8432 \\
\hline SPT0 & -0.14 & 1.39 & 1.86 & 1.86 & 8392 \\
\hline THU3 & 0.32 & 1.04 & 1.57 & 1.6 & 8001 \\
\hline TRDS & -0.56 & 1.26 & 1.52 & 1.62 & 7915 \\
\hline TRO1 & -0.35 & 1.26 & 1.6 & 1.64 & 7940 \\
\hline VAAS & 0.04 & 1.36 & 2.07 & 2.07 & 8402 \\
\hline VARS & -0.06 & 1.42 & 1.89 & 1.9 & 8202 \\
\hline VIL0 & -0.81 & 1.07 & 1.07 & 1.34 & 8274 \\
\hline VIS0 & 0.27 & 1.13 & 1.6 & 1.62 & 8426 \\
\hline WSRT & 1.02 & 1.59 & 1.74 & 2.02 & 8445 \\
\hline
\end{tabular}




\section{Mean temperature for Svalbard and IPW at Hornsund}

To compute IPW from the GPS ZTD estimates, local meteorological data are needed. At Hornsund they were recorded at 3-hour intervals. Meteorological measurements have been interpolated to hourly intervals to comply with hourly GPS ZTD estimates. Fig. 1 demonstrates atmospheric temperature - important meteorological factor conditioning GPS and aerological equipment functioning at Hornsund.

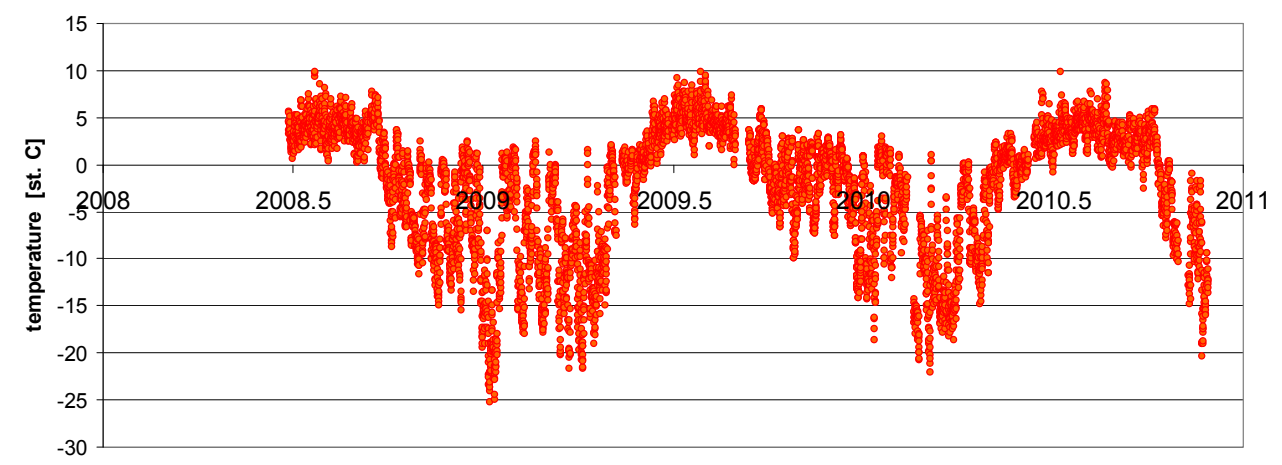

Fig. 1. Atmospheric temperature at Hornsund - the whole of analysed period

Now we can calculate the Integrated precipitable water (IPW) i.e. the total column of water vapour (as liquid). IPW is derived from ZTD solution by widely known procedure; at first we separated wet delay by subtraction of ZHD from ZTD:

$$
Z W D=Z T D-Z H D
$$

Formally ZHD is:

$$
Z H D=\int_{0}^{p_{s}} \frac{R_{d} k_{1}}{g} d p
$$

Where $p$ is atmospheric pressure, $p_{s}$ surface pressure, $R_{d}=287.04[\mathrm{~J} / \mathrm{K} \cdot \mathrm{kg}]$ is specific gas constant for dry air, $g$ is the acceleration due to gravity and non-inertial forces acting upon a particle at rest with respect to the Earth and empirical constant $k_{1}=7.76 \cdot 10^{-7}[\mathrm{~K} / \mathrm{Pa}$ ]. In this work the following Saastamoinen formula has been used to calculate $Z H D$ :

$$
Z H D=(2.2779) p / f(\varphi, H)
$$

Where $f$ function reproduces changes of the force of gravity with latitude $\varphi$ and ellipsoidal height $H$ [given in kilometers] (Davis et al. 1985):

$$
f(\varphi, H)=(1-0.00266 \cos 2 \varphi-0.00028 H)
$$

Next, obtained ZWD is recalculated by coefficient $\mathrm{k}$ which depends on so called 'mean temperature' in vertical profile of atmosphere (Bevis et al. 1992, Rocken et al. 1993). 


$$
I P W \approx \kappa \cdot Z W D
$$

Coefficient $\kappa$ is given by equation:

$$
1 / \kappa=10^{-6}\left(C_{3} / T_{m}+C_{2}^{\prime}\right) R_{v}
$$

and has value of about $1 / 6.4 ; R_{v}$ is specific gas constant for water vapour, $T_{m}$ 'mean temperature', $C_{i}$ are empirical coefficients (given e.g. in Davis et al. 1985). Coefficient $K$ depends on temperature profile but can be estimated by means of surface temperature at the GNSS station (Bevis et al. 1992):

$$
T_{m}=55.8+0.77 \cdot T_{s}[\mathrm{~K}]
$$

It is average formula for mean temperature obtained from 8718 radiosunding profiles in the US for latitudes: $27^{\circ}-65^{\circ} \mathrm{N}$. For Svalbard radiosoundings are performed mostly once a day (at noon) at Ny Alesund (station identifier: ENAS, WMO station number: 1004, latitude $78.91 \mathrm{~N}$, longitude $11.93 \mathrm{E}$, base elevation: $8.0 \mathrm{~m}$ ). Episodic night soundings have been excluded because sunphotometer measurements are performed only in the sunlight. Linear formula for mean temperature obtained here (for the period of 2008-2010) is significantly different from equation 9:

$$
T_{m}=29.3+0.86 \cdot T_{s} \pm 0.9[\mathrm{~K}]
$$

Polar tropopause is lower and relatively warmer in relation to surface than tropopause for mid-latitudes. Relation surface temperature - mean temperature at $\mathrm{Ny}$ Alesund is illustrated on Fig. 2 together with Bevis formula.

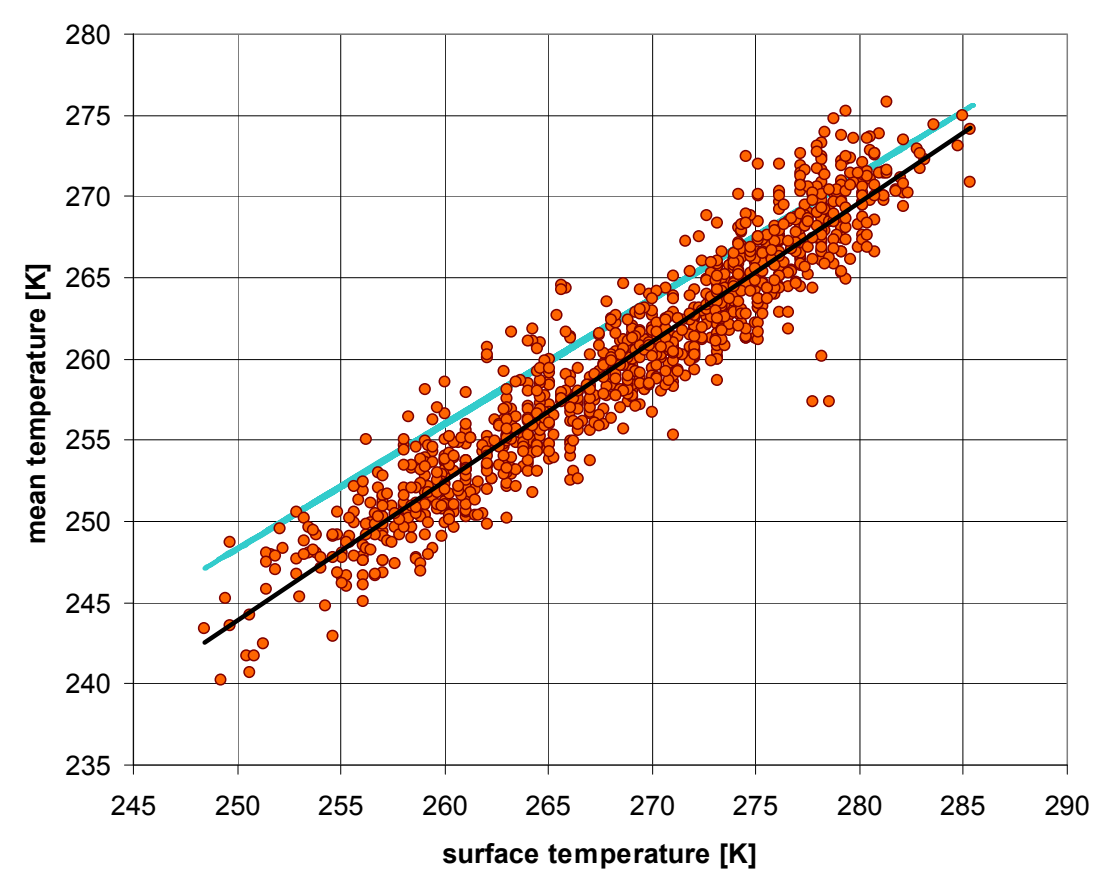

Fig. 2. Mean temperature vs. surface temperature for Ny Alesund, 2008-2010 (1134 soundings), linear formula fitting (black line) and Bevis formula (blue line) 
This local model of mean temperature has been used to derive IPW at Hornsund, also for radiosoundings comparisons for NYA1 GNSS point. Atmospheric pressure for ZHD calculation has been adjusted to GPS antenna height (separately for ASTR and AST0 points) through precise barometric equation including temperature. The IPW obtained in this way is presented in Fig. 3. Local model of mean temperature changes IPW on average by $-0.06 \mathrm{~mm}$ for 2010 (about $-0.1 \mathrm{~mm}$ in the summer) in relation to IPW obtained by Bevis formula.

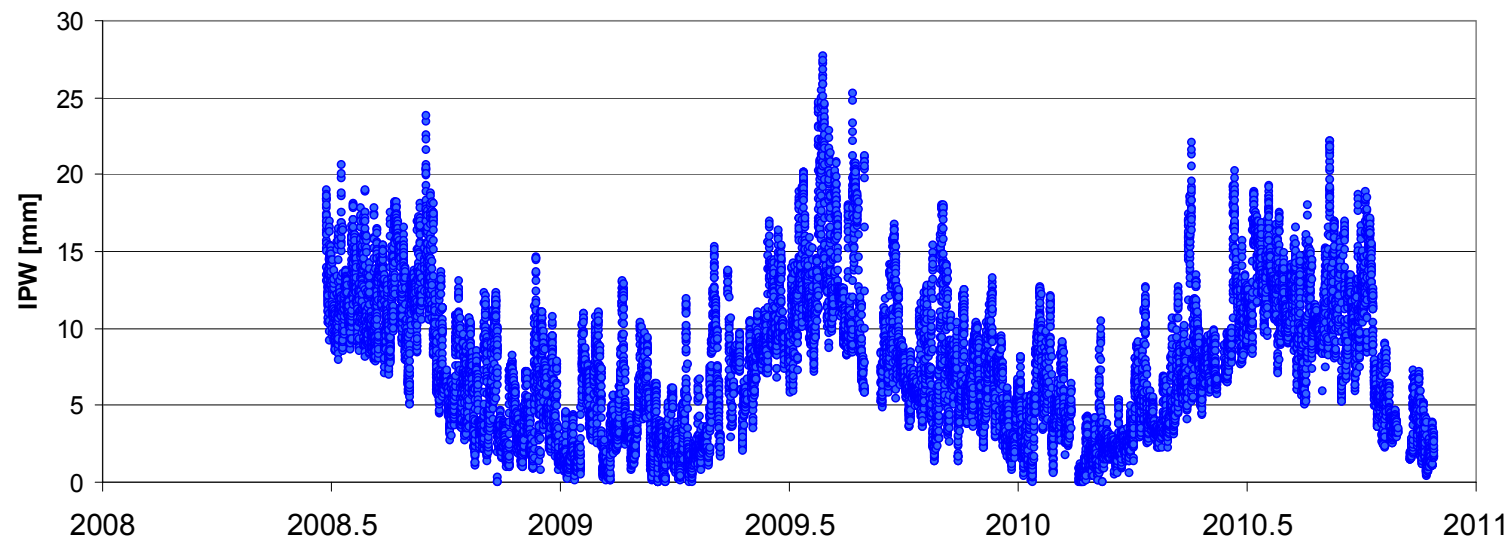

Fig. 3. Hornsund IPW from GPS - the whole of analysed period (19 677 IPW solutions, meteo interpolated in 1 hour interval)

IPW dependence on other meteorological parameters is natural phenomenon. In case of Hornsund there is no relationship IPW - surface atmospheric pressure but IPW and temperature are clearly interrelated (Fig. 4).

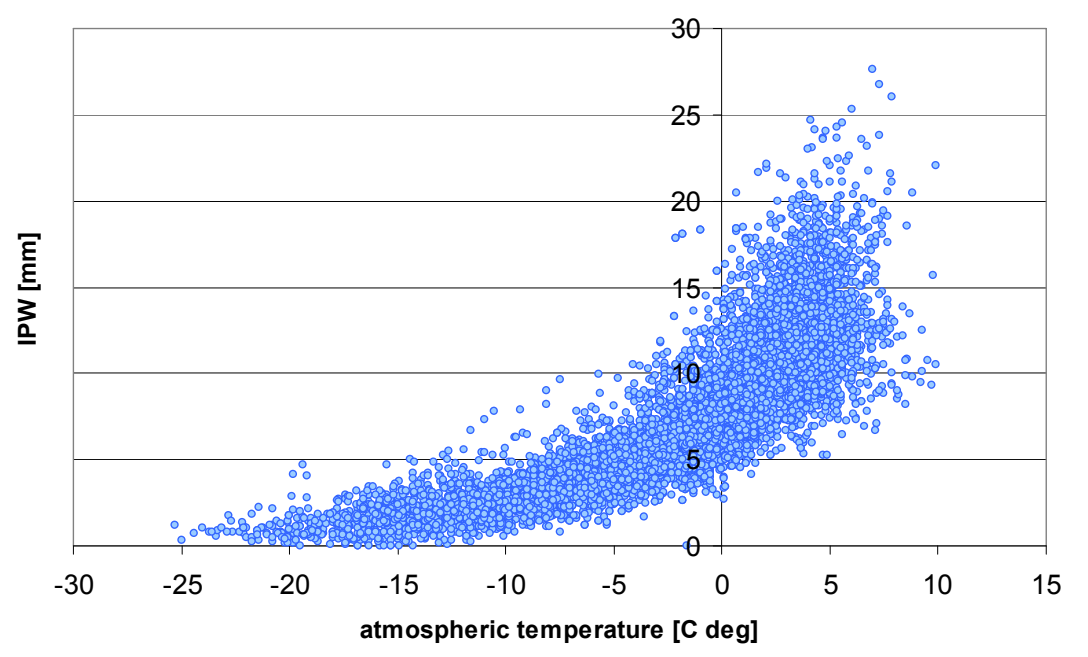

Fig. 4. Hornsund IPW vs. atmospheric temperature - the whole campaign (original 3 hour interval of meteorological measurements)

Figure 4 nicely illustrates limited content of water vapour in low temperatures. So called saturated water vapour pressure (and also density) has extremely close function graph to our chart (compare Mcllven, 2010, figure 6.2). Humidity in polar oceanic climate is always high (on average $82 \%$ in 2009 at Hornsund) - close to saturation. 


\section{Comparisons of the IPW from GPS and Aerological Sources}

There are two entirely independent aerological data sources to obtain IPW at Western Svalbard: radiosoundings at Ny Alesund and CIMEL sunphotometer at Hornsund (Fig. 5). In this section we present the results of technique comparison and some in depth analyses of obtained discrepancies.

\subsection{GPS IPW vs. radiosoundings}

Fundamental aerological technique is balloon soundings called radiosounding. Svalbard soundings performed at Ny Alesund are described in the previous chapter. Permanent GNSS station (NYA1) works also at Ny Alesund and iis located $1.7 \mathrm{~km}$ form RAOB launching point and $40 \mathrm{~m}$ higher. For NYA1 it is possible to compare: EPN combined tropospheric solution, IGS tropospheric product (Byun and Bar-Sever, 2009) and dedicated network solution which is object of this work (this solution includes both NYA1 and Hornsund itself). GPS and RAOB comparisons in the form of ZTD are provided by $\mathrm{H}$. Vedel in the frame of EPN (see:

http://www.epncb.oma.be/ networkdata/radiosonde zpd biases.php?station=NYA1 10317M003).

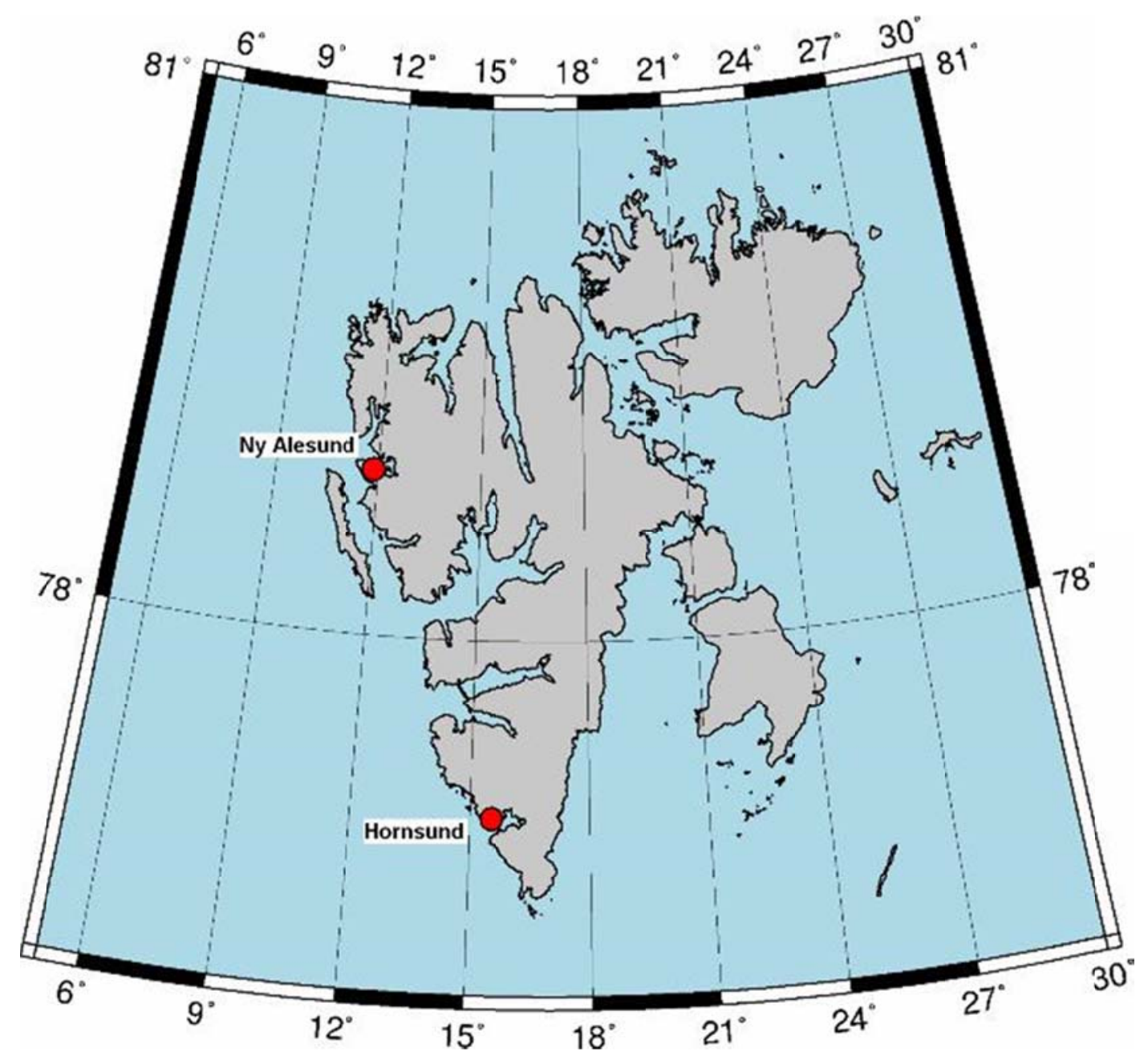

Fig. 5. Polish Polar Station Hornsund and Ny Alesund (created by GMT) 
To calculate IPW for NYA1 that has no meteo devices at GPS station we have used meteo data at the base of the sounding taking into account height difference (40 m ASL). Integrated Precipitable Water for radiosounding profile can be obtained by numerical integration of average water vapour density (calculated from temperature and relative humidity for each level $j$ and averaged between registered levels, from surface reading $j=0$ up to the last level $N$ ):

$$
\left.I P W=\sum_{k=1}^{N} \overline{\rho_{w v}(j-1, j}\right)\left(h_{j}-h_{j-1}\right)
$$

IPW values from the two techniques are set aside in Fig. 6. Degradation of IPW information with distance: $1.7 \mathrm{~km}$ (for NYA1) and $228 \mathrm{~km}$ (for Hornsusnd) is clearly visible. The differences are presented and to some degree analysed in Fig. 7 and Tab. 2.
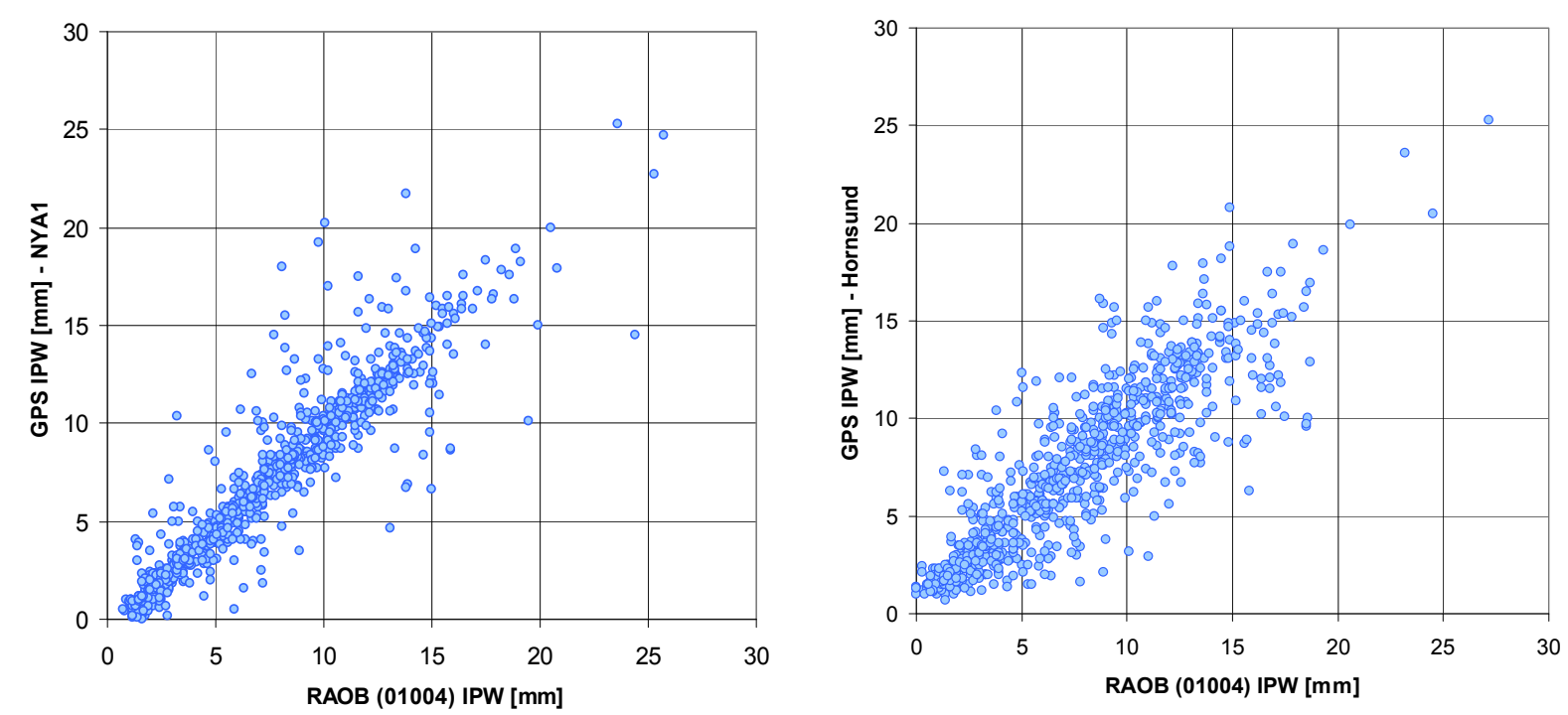

Fig. 6. Ny Alesund RAOB IPW vs. NYA1 GPS IPW (EPN tropospheric combination) and Hornsund GPS (dedicated solution) in the period of the whole campaign

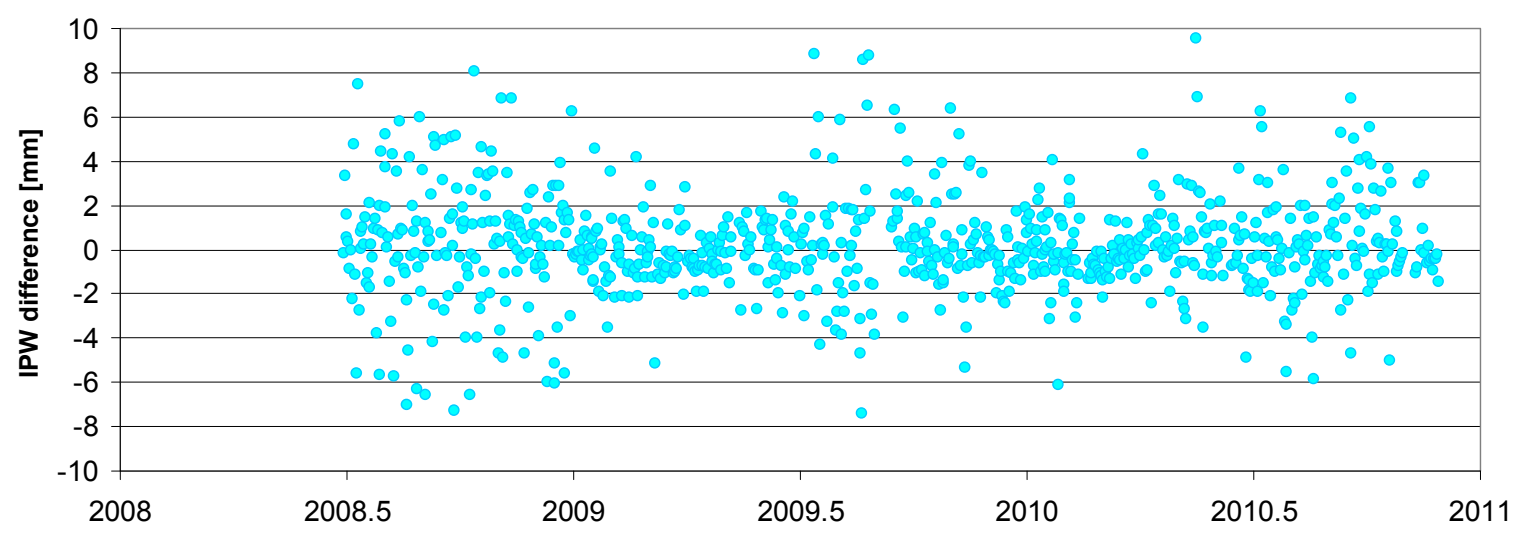

Fig. 7. IPW differences (Hornsund GPS IPW - Ny Alesund RAOB IPW) for the whole campaign (difference sign set opposite to the table 2) 
Table 2. Comparison of IPW differences (RAOB - GPS) from Ny Alesund RAOB and Hornsund or NYA1 tropospheric GPS solution, EPN tropospheric combination and IGS tropospheric product (hourly averages of 5 minute estimates)

\begin{tabular}{|c|c|c|c|c|c|c|c|}
\hline GPS station & GPS solution & year & bias [mm] & $\begin{array}{c}\text { mean absolute } \\
\text { bias [mm] }\end{array}$ & $\begin{array}{c}\text { difference } \\
\text { STDEV }[\mathrm{mm}]\end{array}$ & $\begin{array}{l}\text { difference } \\
\text { RMS [mm] }\end{array}$ & points \\
\hline \multirow{3}{*}{ Hornsund } & \multirow{3}{*}{$\begin{array}{l}\text { Hornsund } \\
\text { dedicated }\end{array}$} & 2008 & -0.29 & 2.34 & 3.17 & 3.18 & 186 \\
\hline & & 2009 & -0.08 & 1.44 & 2.20 & 2.20 & 332 \\
\hline & & 2010 & -0.16 & 1.37 & 1.96 & 1.96 & 309 \\
\hline \multirow{3}{*}{ NYA1 } & \multirow{3}{*}{$\begin{array}{l}\text { Hornsund } \\
\text { dedicated }\end{array}$} & 2008 & 0.54 & 2.72 & 3.52 & 3.56 & 195 \\
\hline & & 2009 & 0.56 & 0.86 & 1.07 & 1.21 & 344 \\
\hline & & 2010 & 0.62 & 0.78 & 0.97 & 1.15 & 336 \\
\hline \multirow{3}{*}{ NYA1 } & \multirow{3}{*}{ EUR comb. } & 2008 & 0.69 & 1.97 & 2.67 & 2.75 & 432 \\
\hline & & 2009 & 0.65 & 0.87 & 1.01 & 1.20 & 350 \\
\hline & & 2010 & 0.61 & 0.76 & 0.92 & 1.10 & 370 \\
\hline \multirow{2}{*}{ NYA1 } & \multirow{2}{*}{ IGS tropo } & 2009 & 0.97 & 1.09 & 0.98 & 1.38 & 351 \\
\hline & & 2010 & 0.95 & 1.19 & 1.30 & 1.61 & 287 \\
\hline
\end{tabular}

Although scattering increases with distance, the bias (RAOB - GPS) is smaller for Hornsund than Ny Alesund. IPW bias is biggest for IGS tropospheric solution. Correlation coefficient for IPW series of Hornsund GPS IPW and Ny Alesund RAOB is only 0.87 but there is no significant bias - for the whole Hornsund campaign only $0.14 \mathrm{~mm}$ (after exclusion of outliers exceeding $3 \sigma$ threshold). Probable cause to this is climate difference. The distance from Hornsund to Ny Alesund is $228 \mathrm{~km}$ in NWN direction and for Ny Alesund warming influence of Gulf Current is slightly weaker. Temperature readings for Hornsund at comparison moments are on average $1.2^{\circ} \mathrm{C}$ higher than surface readings in Ny Alesund soundings.

Next important notice is presented on Fig.8. There is no dependence of IPW difference on temperature (both stations Hornsund and NYA1 mean).

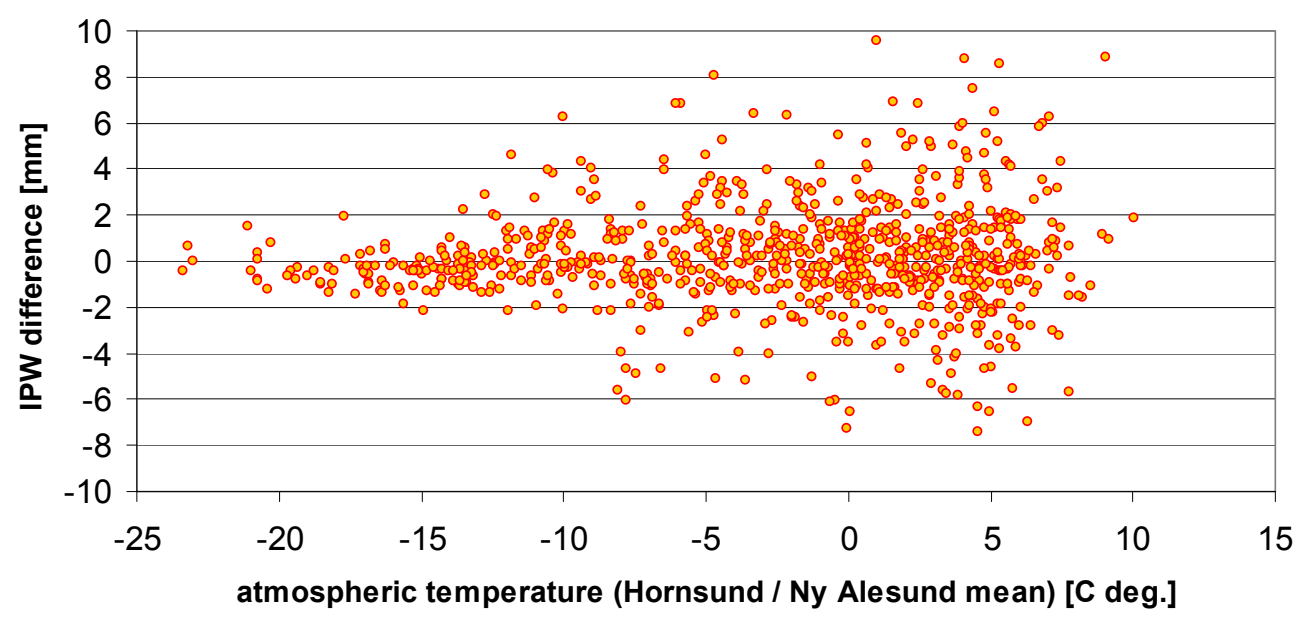

Fig. 8. IPW differences (Hornsund GPS - Ny Alesund RAOB IPW) wrt. the mean temperature at both stations, the whole campaign 


\subsection{GPS IPW vs. CIMEL sunphotometer}

Main problem here is very sparse sunphotometer measurements at Hornsund. Due to polar night only part of the year is covered and measurements are generally at low elevation of the sun. Measurements start at above $10^{\circ}$ over the horizon (see Fig. 9) and are possible only from March to September. These problems are accompanied by frequent cloudy weather - typical for arctic oceanic climate. Tropospheric solution (just like the station height) is also less precisely estimated in polar region because of satellite constellation geometry (which is testified by high VDOP). GPS observations can be affected by poor visibility and low SNR ratio for satellites at low elevations. In this work level 1.5 (cloud-screened) AERONET product is used: it has more points and level 2.0 does not improve IPW. Sunphotometer measurements have been averaged in 1 hour intervals.

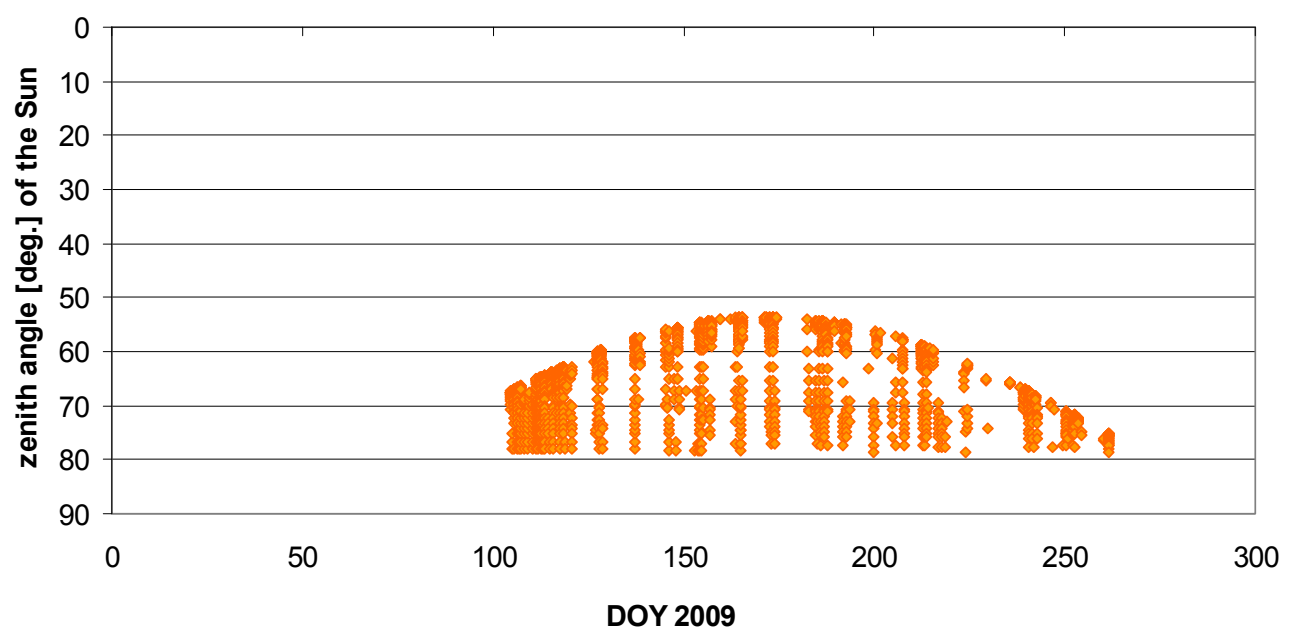

Fig. 9. Zenith angle of CIMEL- 318 measurements at Hornsund in 2009

Figures 10 and 11 present results of CIMEL- GPS IPW comparisons at Hornsund and table summarises the results for subsequent years.

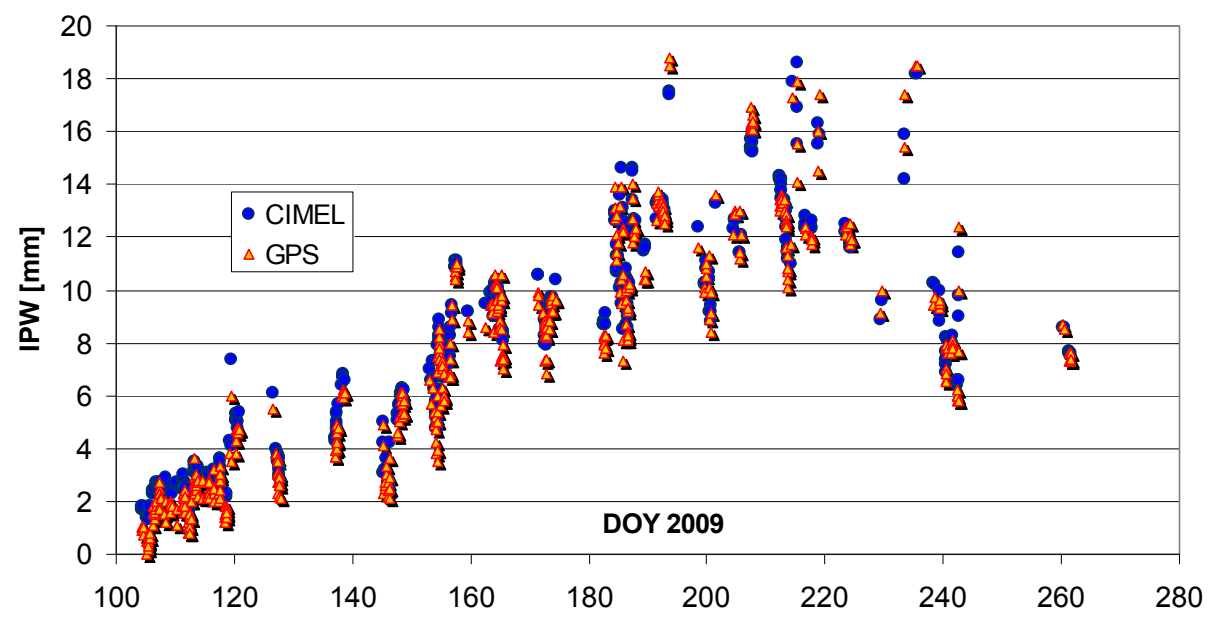

Fig. 10. Hornsund IPW from CIMEL-318 measurements and GPS in 2009 (only hours with both measurements available) 


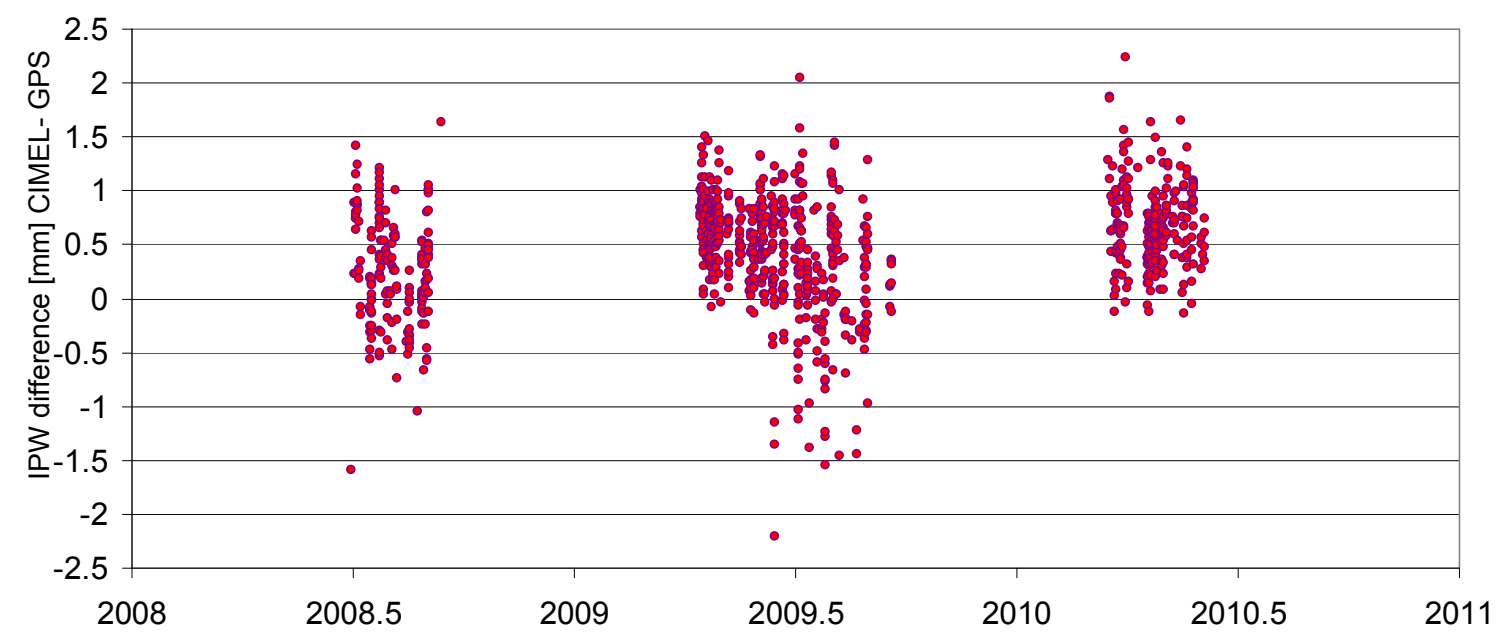

Fig. 11. Hornsund IPW difference (CIMEL-318 measurements minus GPS) for the whole of analysed period

Table 3. Comparison of IPW from CIMEL CF-318 and IPW from test campaign (WUT LAC network solution for Hornsund) divided by years and GPS points (ASTR/AST0)

\begin{tabular}{|c|c|c|c|c|c|c|}
\hline & $\begin{array}{c}\text { IPW average } \\
\text { difference }[\mathrm{mm}]\end{array}$ & $\begin{array}{c}\text { IPW average absolute } \\
\text { difference }[\mathrm{mm}]\end{array}$ & $\begin{array}{c}\text { difference } \\
\text { STDEV [mm] }\end{array}$ & $\begin{array}{c}\text { RMS } \\
{[\mathrm{mm}]}\end{array}$ & $\begin{array}{c}\text { GPS } \\
\text { estimates }\end{array}$ & $\begin{array}{c}\text { photometric } \\
\text { measurements }\end{array}$ \\
\hline 2008 & 0.25 & 0.44 & 0.5 & 0.56 & 174 & 499 \\
\hline 2009 & 0.42 & 0.58 & 0.53 & 0.68 & 498 & 1386 \\
\hline 2010 & 0.67 & 0.68 & 0.37 & 0.77 & 245 & 487 \\
\hline \hline ASTR & 0.26 & 0.43 & 0.49 & 0.55 & 182 & 527 \\
\hline AST0 & 0.51 & 0.61 & 0.48 & 0.71 & 735 & 1845 \\
\hline
\end{tabular}

IPW bias (CIMEL - GPS) for the whole campaign is $0.46 \mathrm{~mm}$. IPW bias is 2 times bigger for the second GPS antenna location (AST0) than the point ASTR. If it is the effect of higher location (only 8 meters higher elevation) seems questionable. More probable case is stochastics: there are only 182 comparison points for ASTR.

For the whole analysed period there are only 917 GPS comparison points (hourly intervals) so it's better to treat the whole data set together for further analysis. IPW bias changes with IPW value as can be seen on figure 12. This bias shows disturbed histogram (Fig. 13) changes with season (Fig. 14) and is function of atmospheric temperature (Fig. 15). 


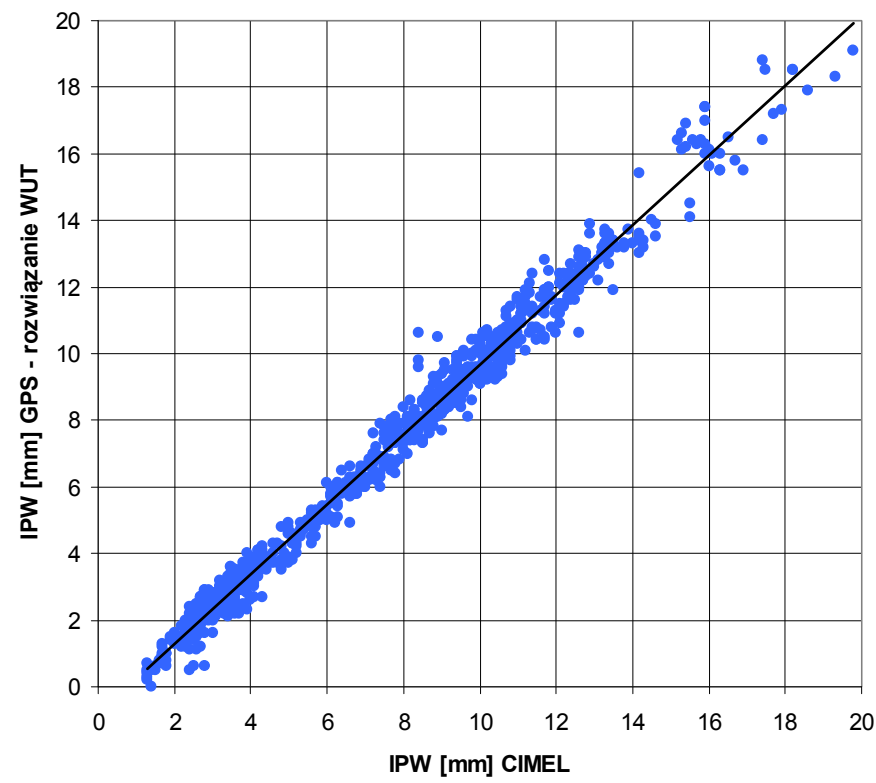

Fig. 12. Hornsund IPW from GPS vs. IPW for CIMEL-318 measurements for the whole campaign (2008-2010)

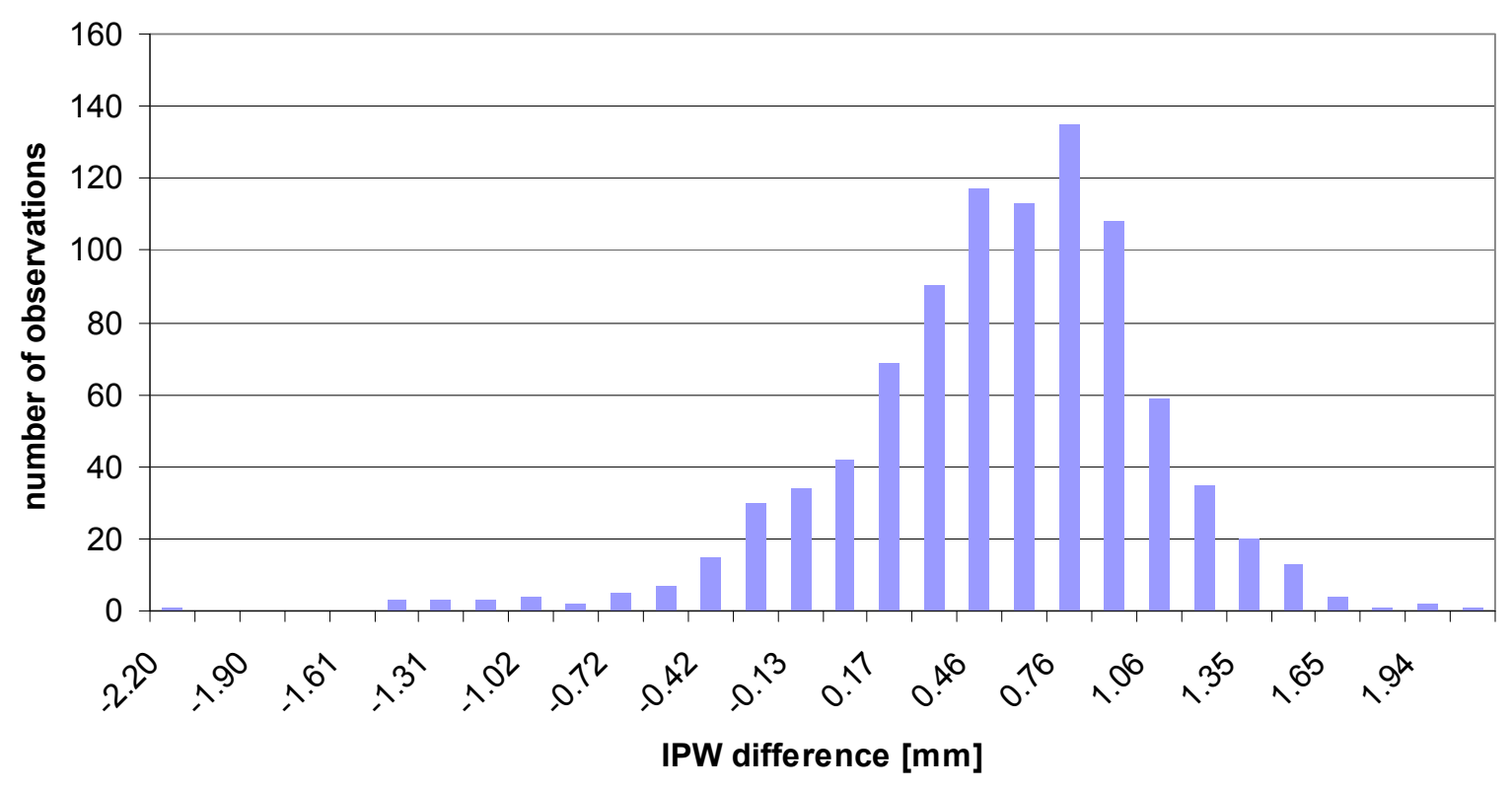

Fig. 13. IPW difference histogram at Hornsund (CIMEL-318 measurements minus GPS) for the whole campaign (2008-2010) 


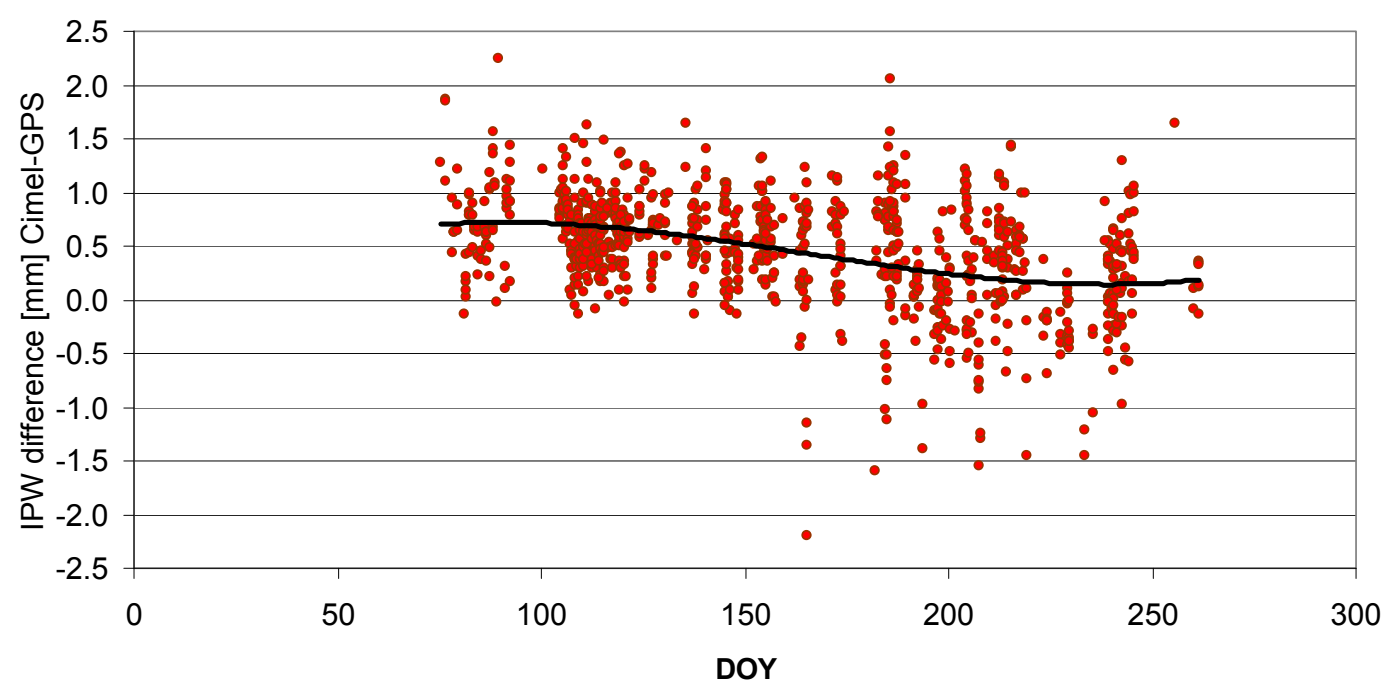

Fig. 14. IPW difference at Hornsund from CIMEL-318 measurements minus GPS for the whole campaign (2008-2010) in the function of day of year

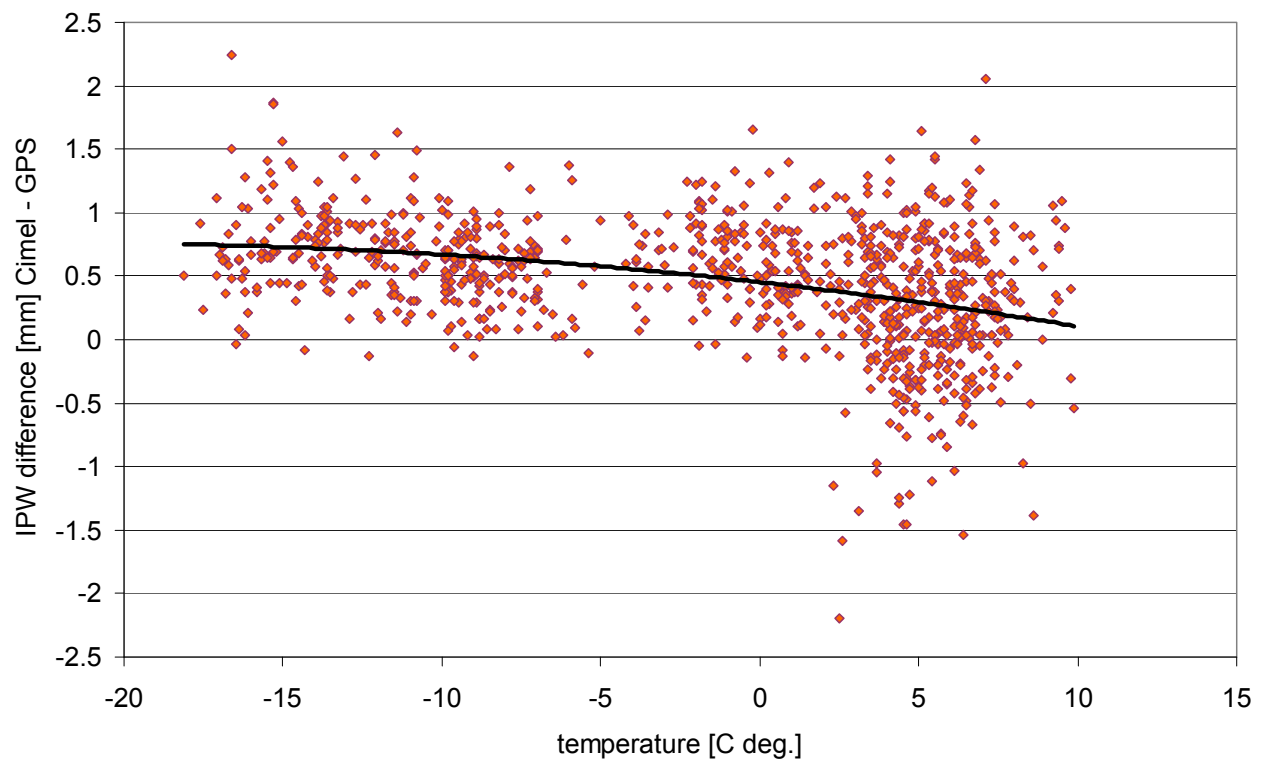

Fig. 15. IPW difference (CIMEL-318 - GPS) for Hornsund in 2008-2010 wrt. surface atmospheric temperature

In polar environment with different sun visibility, GPS constellation geometry and temperature range IPW series from GPS and sunphotometer differ more than in Central Europe where we have got excellent conformity in similar experiment (to be published as: Kruczyk at al., 2015). This phenomenon probably reflects temperature dependence of transmittance parameters of the optical filter (filter response functions) in CIMEL-318; the instruments of this type are not thermostatised (A. Pietruczuk - personal communication). There is ongoing work with the procedure of IPW retrieval form sunphotometer measurements (Alexandrov et al., 2009). Relatively low accuracy of IPW (10 \%) measured by sunphotometer are acknowledged in several works (e.g. Pérez-Ramírez et al., 2014). 


\subsection{CIMEL Sunphotometer vs. Radiosundings}

CIMEL sunphotometer IPW measurements and RAOB IPW have been also compared for the period of 2005-2010. There are only 187 points of CIMEL-RAOB comparison for this period (for the campaign period only about half that number) after $3 \sigma$ outliers' removal. It is no use to break results on annual basis. For the whole 2005-2010 period IPW bias (CIMEL-RAOB) is only $0.08 \mathrm{~mm}$, standard deviation is $1.7 \mathrm{~mm}$ (1.4 mm without outliers). We should get smaller IPW values from radiosundings: Ny Alesund is $228 \mathrm{~km}$ north and on average $1.1^{\circ} \mathrm{C}$ colder (in comparison moments). Note that RAOB - GPS IPW bias is negative for Hornsund dedicated solution. Data set for RAOB-CIMEL comparison is not wholly representative: both measurements take place only at noon during polar day. However it demonstrates some aerological techniques deficiencies: differences also show dependence on atmospheric temperature (Fig. 17).

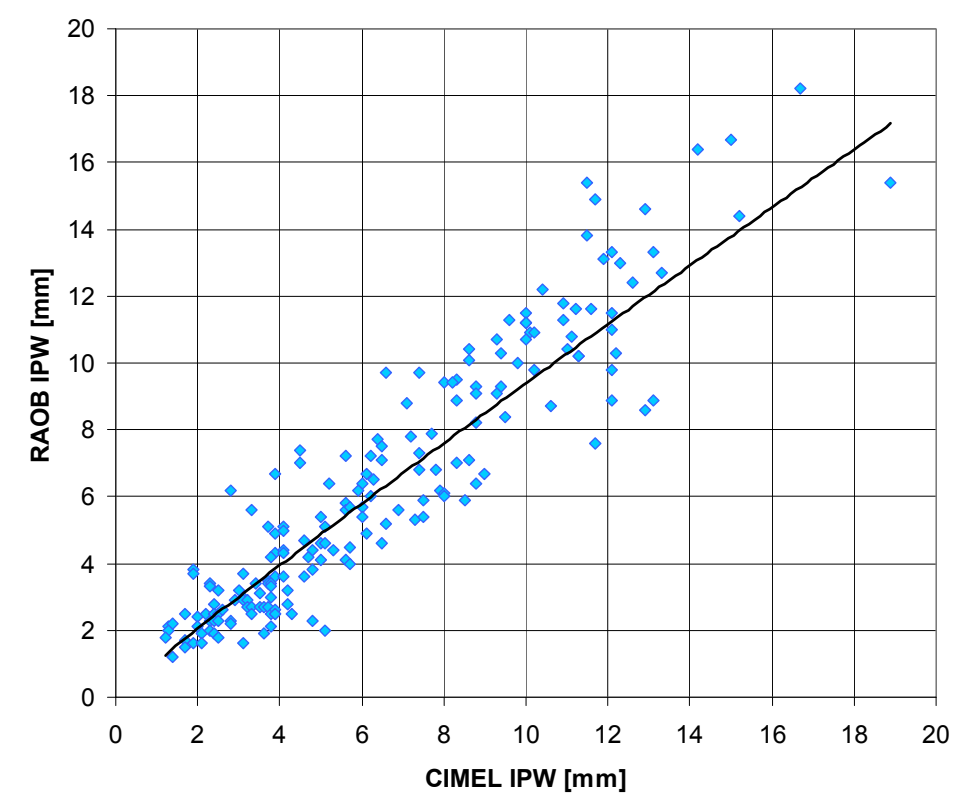

Fig. 16. Hornsund IPW from CIMEL-318 measurements and Ny Alesund RAOB (2005-2010)

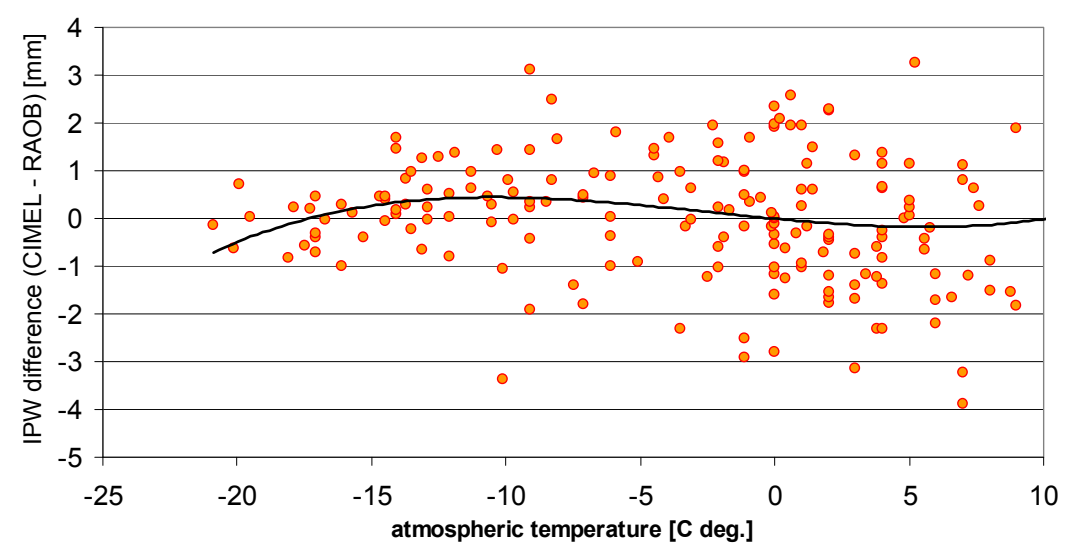

Fig. 17. IPW difference (CIMEL-318 for Hornsund - RAOB for Ny Alesund) as a function of the surface atmospheric temperature (2005-2010) 


\section{Conclusions}

Three independent techniques have been tested to obtain Integrated Precipitable Water at Svalbard: GPS solution, radiosounding and CIMEL sunphotometer.

GPS network solution for Hornsund has been verified thanks to EPN tropospheric combination and is of good quality.

To calculate IPW for Hornsund local model of the mean temperature has been developed using radiosoundings at Ny Alesund. Linear formula for mean temperature obtained here is considerably different from the formula obtained by Bevis for stations in mid-latitudes bacause polar tropopause is lower and relatively warmer in relation to surface than tropopause for mid-latitudes

IPW difference for RAOB-GPS is relatively small and show no dependence on temperature for both Hornsund and NYA1 stations. RAOB IPW bias depends on GPS solution.

CIMEL sunphotometer IPW and IPW values derived by in situ observation campaign for Hornsund show relatively good agreement but also bias of $5 \%(0.46$ $\mathrm{mm}$ ). IPW bias shows seasonal dependence what signals some systematic deficiencies in solar photometry as IPW retrieval technique. Probable cause to this phenomena is a change of optical filter characteristics in sunphotometer working in polar conditions.

The attempt to compare aerological techniques (CIMEL and RAOB) brings similar but less pronounced results.

In polar environment with different sun visibility, GPS constellation geometry and temperature range, IPW series obtained by GPS and aerology show some characteristic discrepancies. There is empirical basis to claim that GPS solution gives us at least as reliable results of IPW in polar region as expert aerological techniques.

\section{Acknowledgements}

- This research was financially supported by the grant No. N N526 074038 of the Polish Ministry of Science and Higher Education/ National Science Centre;

- Aleksander Pietruczuk, Piotr Sobolewski, Dariusz Puczko, Institute of Geophysics, Polish

Academy of Sciences;

- NASA, AERONET (Brent Holben) - sunphotometer data;

- University of Wyoming - radiosounding data;

- Kinga Węzka, TU Berlin - GPS data preparation.

\section{References}

Alexandrov, M.A., Schmid, B., Turner, D.D., Cairns, B., Oinas, V., Lacis, A.A., Gutman, S.I., Westwater, E.R., A. Smirnov and J. Eilers, (2009). Columnar water vapor retrievals from MFRSR data, J.Geophys.Res., 114, D02306, doi:10.1029/2008JD010543

Bevis, M., Businger, S., Herring, T., Rocken, C., Anthes, R., \& Ware, R. (1992): GPS Meteorology: Remote Sensing of Atmospheric Water Vapour using the Global Positioning System, J. Geophys. Res., 97, pp 15,787-15,801

Byun, S. H., Bar-Sever, Yoaz E. (2009). A new type of troposphere zenith path delay product of the international GNSS service. J Geod (2009) 83: pp 367-373, doi: $10.1007 / \mathrm{s} 00190-008-0288-8$ 
Dach, R., U. Hugentobler, P. Fridez, M. Meindl (2007) Bernese GPS Software Version 5.0. User manual, University of Bern, 2007

Davis, J. L., Herring, T. A., Shapiro, I. I., Rogers A. E., \& Elgered, G. (1985). Geodesy by radio interferometry: Effects of atmospheric modeling errors on estimates of baseline length, Radio Sci., 20, pp 1593-1607. doi:10.1029/RS020i006p01593

Duan, J., Bevis, M., Fang, P., Bock, Y., Chiswell, S., Businger, S., Rocken, C., Solheim, F., Van Hove, T., Ware, R., McClusky, S., Herring, T. A. \& King, R. W. (1996). GPS meteorology: direct estimation of the absolute value of precipitable water. J. Applied Met. 35, 830-838. doi:10.1175/1520-0450

Halthore, R.N., Eck, T.F., Holben B.N., \& Markham, B.L. (1997). Sunphotometric Measurements of Atmospheric Water Vapor Column Abundance in the 940-nm Band. J. Geophys. Res., 102, pp 4343-4352

Holben, B.N., Tanre, D., Smirnov, A., Eck, T.F., Slutsker, I., N.Abuhassan, W.W.Newcomb, J.Schafer, B.Chatenet, F.Lavenue, Y.J.Kaufman, J.Vande Castle, A.Setzer, B.Markham, D.Clark, R.Frouin, R.Halthore, A.Karnieli, N.T.O'Neill, C.Pietras, R.T.Pinker, K.Voss, and G.Zibordi, (2001). An emerging ground-based aerosol climatology: Aerosol Optical Depth from AERONET, J. Geophys. Res., 106, pp 12 067-12 097

Hofmann-Wellenhof B., Lichtenegger, H., Wasle E. (2008). GNSS - Global Navigation Satellite Systems GPS, GLONASS, Galileo, and more. Springer Wien NewYork

Kruczyk, M., Liwosz, T., Pietruczuk, A. (2015): Integrated Precipitable Water from GPS Observations and CIMEL Sunphotometer Measurements at CGO Belsk, submitted to Artificial Satellites

Liwosz, T., Kruczyk, M., Rogowski, J. (2010). WUT LAC Report. Paper presented at 7th EUREF LAC EUREF Analysis Workshop, Warsaw, November 18-19 2010 (http://www.epncb.oma.be/ newsmails/workshops/EPNLACWS 2010/day1/s2/8 wut lac report.pdf)

Mcllven, R. (2010). Fundamentals of Weather and Climate, Second Edition, Oxford University Pess

Pérez-Ramírez, D., D.N.Whiteman, A.Smirnov, H.Lyamani, B.Holben, R.Pinker, M.Andrade, L.Alados-Arboledas, (2014). Evaluation of AERONET precipitable water vapor versus microwave radiometry, GPS and radiosondes at ARM sites, J. Geophys. Res. - Atmos., 119, doi:10.1002/ 2014JD021730

Rocken, C., Ware, R., Van Hove, T., Solheim, F., Alber, C., Johnson, J., Bevis, M., and S. Businger, (1993). Sensing atmospheric water vapor with the Global Positioning System, Geophys. Res. Lett., 20, 2631 
Vedel, H., Mogensen, K. S., Huang, X.-Y. (2001). Calculation of zenith delays from meteorological data, comparison of NWP model, radiosonde and GPS delays. Phys. Chem. Earth, Vol. 26, No. 6-8, pp. 497-502

\title{
Authors:
}

\author{
Michał Kruczyk ${ }^{1)}$, kruczyk@gik.pw.edu.pl \\ Tomasz Liwosz 1), tl@gik.pw.edu.pl \\ 1) Department of Geodesy and Geodetic Astronomy \\ Faculty of Geodesy and Cartography \\ Warsaw University of Technology \\ PI. Politechniki 1, 00-661, Warsaw, Poland
}

